\title{
Maternal and fetal outcomes in pregnancies complicated by overweight and obesity
}

\author{
Joice Monaliza Vernini', Jusciele Brogin Moreli ${ }^{1}$, Claudia Garcia Magalhães², Roberto Antônio Araújo Costa²,
} Marilza Vieira Cunha Rudge ${ }^{1,2}$ and Iracema Mattos Paranhos Calderon ${ }^{1,2^{*}}$

\begin{abstract}
Background: Overweight and obesity are associated with pregnancy complications and adverse perinatal outcomes, posing short and long-term risks for maternal and child health. This study evaluated maternal, delivery and neonatal outcomes in pregnancies complicated by overweight and obesity.

Methods: This prospective cross-sectional study included 258 pregnant women. According to prepregnancy body mass index (BMI), participants were classified as normal weight, overweight, or obese. Data were analyzed using the chi-square test and analysis of variance followed by the Tukey test. Logistic regression was performed to calculate odds ratios and $95 \%$ confidence intervals $(p<0.05)$.

Results: Most women $\geq 35$ years old were overweight (22.7\%) and obese (27.6\%). Prepregnancy diabetes was significantly associated with obesity $(15.7 \%, p<0.000)$. Obese women showed the lowest weight gain $(9.6 \pm 7.5 \mathrm{Kg})$. Overweight and obese women practiced physical exercise more frequently $(p=0.010)$ than normal weight women. A greater proportion of obese mothers $(13.4 \%)$ had large for gestational age babies $(p=0.021)$, with higher thoracic circumference $(33.6 \pm 2.0 \mathrm{~cm})$ and abdominal circumference $(31.6 \pm 2.3 \mathrm{~cm})$. Obesity increased the risk of developing hypertension ( $\mathrm{OR}=7.0 ; 3.1-15.9)$, hyperglycemic disturbances $(\mathrm{OR}=5.5 ; 2.9-10.6)$ and $\mathrm{HbA} 1 \mathrm{c} \geq 6$. $5 \%(\mathrm{OR}=3.7 ; 1.2-11.1)$. The infants born to obese mothers had longer hospital stay (3.9 \pm 3.9 days) $(p=0.005)$. Conclusion: Our results confirm that obesity in pregnancy can lead to adverse outcomes, and underscore the importance of identifying and treating inadequate weight status during pregnancy.
\end{abstract}

Keywords: Obesity, Overweight, Pregnancy, Maternal outcomes, Perinatal outcomes

\section{Background}

Overweight and obesity are defined as abnormal or excess accumulation of adipose tissue in the body. These conditions are caused by a combination of genetic, metabolic, behavioral, environmental, cultural, and socioeconomic factors. Overweight and obesity are public health problems that contribute to preventable deaths each year, and the number of overweight and obese women at reproductive age is increasing in many countries $[1,2]$.

\footnotetext{
* Correspondence: calderon@fmb.unesp.br

${ }^{1}$ Graduate Program in Gynecology, Obstetrics and Mastology, Botucatu Medical School, São Paulo State University - Unesp, São Paulo, Brazil

${ }^{2}$ Department of Obstetrics and Gynecology, Botucatu Medical School, São

Paulo State University - Unesp, São Paulo, Brazil
}

Since pregnancy can serve as a triggering or aggravating factor for obesity [3, 4], diagnosing and monitoring the weight status of pregnant women should be a routine prenatal care procedure $[5,6]$. A number of factors, such as water retention, uterine growth, formation of fetal tissues and placenta, and increasing amniotic fluid volume, can limit the evaluation of maternal body mass index (BMI) during pregnancy $[7,8]$. Therefore, since 2004, the Brazilian Ministry of Health has issued guidelines for categorizing ideal gestational weight gain based on prepregnancy BMI. These guidelines, recommend assessing a woman's nutritional status during pregnancy using a specific tool [6] which was developed based on Atalah's curve [9] and IOM recommendations [8]. 
Overweight pregnant women have higher risks of hypertension, gestational diabetes mellitus (GDM), Cesarean section, shoulder dystocia and early neonatal death [10-14]. Obesity in pregnancy compromises fetal metabolic programming, increasing the risk of obesity, diabetes and cardiovascular disorders in the offspring $[15,16]$.

Thus, the present study aimed at evaluating maternal, delivery and neonatal outcomes in pregnancies complicated by overweight and obesity.

\section{Methods}

\section{Study design and subjects}

This is a prospective cross-sectional study including 258 pregnant women and their infants. Based on prepregnancy weight as self-reported during the first prenatal visit, pregnant women were classified according to BMI as normal weight $\left(18.5-24.9 \mathrm{Kg} / \mathrm{m}^{2} \mathrm{BMI} ; n=65\right)$; overweight $\left(25.0-29.9 \mathrm{Kg} / \mathrm{m}^{2}\right.$ BMI; $\left.n=66\right)$; or obese (BMI $\geq$ $\left.30.0 \mathrm{Kg} / \mathrm{m}^{2} ; n=127\right)$ [17].

Ethics approval was granted by the Human Research Ethics Committee of Botucatu Medical School-Unesp, and written informed consent was obtained from all study participants.

\section{Inclusion and exclusion criteria}

Inclusion criteria were prenatal care commencing up to 20 weeks of gestationand singleton pregnancy. Underweight pregnant women were excluded.

\section{Data collection}

During the first prenatal visit (before 20th gestational week), the following maternal characteristics were evaluated: age (full years); number of gestations including current pregnancy; previous Cesarean section; smoking habits, history of hypertension and diabetes mellitu$\mathrm{s}$, and family history of diabetes, obesity, hypertension, cardiovascular disease and hypercholerestolemia. At the end of gestation (37th to 38th gestational week), maternal pregnancy outcomes were evaluated based on final pregnancy weight; gestational weight gain; gestational $\mathrm{BMI}$; practice of light to moderate-intensity exercises during pregnancy (yes or no); and intercurrent diseases (such as urinary infection, genital infection, gestational hypertension, preelampsia, hyperglycemic disorders (mild gestational hyperglycemia - MGH, and gestational diabetes mellitus - GDM) $[18,19]$, and glycated hemoglobin $(\mathrm{HbA1c})$ levels in the third trimester of pregnancy.

Data collected at birth included mode of delivery (vaginal or C-section); gestational age; New Ballard scores; birth weight; birth weight/gestational age category; ponderal index [(birth weight/lenght $\left.\left.{ }^{3}\right) \times 100\right]$; length; circumference of the head, thorax, and abdomenl; 1, 5 and
10 min Apgar scores; placenta weight; and placental index (PI = placenta weight/birth weight). In the cord blood, the levels of glucose, hematocrit, hemoglobin, bilirubin, and white and red blood cells were evaluated.During the neonatal period, information on hypoglycemia episodes; need for phototherapy; malformations and infant hospital stay length was obtained.All data were recorded on forms specifically developed for the study.

\section{Follow-up}

All women received follow up care at the Diabetes and Pregnancy Referral Center of Botucatu Medical SchoolUnesp. Reasons for referral were previous diabetes mellitus (type 1-DM or type 2-DM) or risk of developing hyperglycemic disorders [20], i.e. gestational diabetes mellitus (GDM) and mild gestational hyperglycemia (MGH) $[17,19]$.

According to our center's routine protocol [18, 19], diabetic pregnant women (type 1-DM or type 2-DM) were immediately managed with glycemic control, individualized nutritional intervention, and a light to moderateintensity exercise program (most frequently walking for 30 minutes five times a week). Insulin therapy was introduced when necessary [21].

Pregnant women who were nondiabetic, but were overweight or obese, were advised as to the importance of lifestyle changes to prevent GDM and MGH, and were promptly assigned to individualized nutritional guidance and home walking for 30 minutes five times a week for weight control during pregnancy. Regardless of these preventive measures, all nondiabetic pregnant women underwent glucose tolerance (75 g-OGTT) and gycemic profile (GP) testing between 24 and 28 weeks of pregnancy for confirmation or ruling out of GDM and MGH [18-20]. Pregnant women with confirmed GDM or MGH were treated according to the same protocol to achieve glycemic control. Insulin therapy was introduced when necessary. Glycemic control and management of diabetes were evaluated by 24-h GP (fasting, pre- and post- prandial glycemic levels) performed at 2-week intervals until week 32 , and weekly until delivery [18-20].

\section{Statistical analyses}

Data were systematically transferred from medical records to Microsoft Excel 2010. Statistical analyses were performed using SAS 9.2 for Windows. Data frequencies (in percentage) were compared using the chi-square test; means were evaluated by analysis of variance (ANOVA), followed by the Tukey-Kramer test for multiple comparisons. Data on maternal, neonatal and delivery outcomes were assessed using logistic regression to calculate odds ratios with confidence intervals (CI $95 \%$ ). Significance level was set at $p<0.05$. 


\section{Results}

Overweight and obesity predominated among pregnant women $\geq 35$ years, whereas normal weight was most frequently observed among pregnant adolescents ( $\leq 19$ years old) $(p<0.001)$. Prepregnancy diabetes was more frequent in obese $(15.7 \%)$ and overweight (13.6 \%) women than in women with normal weight (6.2\%). The prevalence of of family history of obesity was greater in obese and overweight women, although not statistically significant $(p=0.051)$ (Table 1$)$.

Compared to women with normal weight, overweight and obese women showed higher mean baseline weight and final weight, prepregnancy BMI and gestational BMI (at 37-38 weeks of pregnancy) $(p<0.001)$. Nonetheless, weight gain (WG) was lowest in the obese group (Table 2).

WG $<8 \mathrm{Kg}$ was more frequent among the obese, while excess WG (WG $>16 \mathrm{~kg}$ ) was more frequently seen in women with normal weight $(p<0.001)$. By the end of pregnancy, most normal weight women were either overweight $(35.4 \%)$ or obese $(3.1 \%)(p<0.001)$. Most overweight and obese women engaged in physical activity during pregnancy $(p=0.010)$, and developed either GDM $(p<0.001)$ or MGH $(p=0.005)$. Irrespective of group, over $80.0 \%$ of the pregnant women with hyperglycemia exhibited normal HbA1c levels $(<6.5 \%)$ in the third trimester of pregnancy, with no differences among groups $(p=0.075)$ (Table 2$)$.

Obese women had the highest rate of LGA (13.4\%) and the lowest rate of SGA infants $(4.7 \%)(p=0.021)$; with $40.9 \%$ of these infants showing disproportionate growth (IP $\geq 2.98)(p=0.037)$. Mean thoracic circumference $(p=0.006)$, abdominal circumference $(p=0.032)$, placental weight $(p<0.001)$ and placental index $(p=0.037)$ were higher in the obese group (Table 3 ). The infants born to obese mothers remained in hospital for a longer period $(p=0.005)$, but maternal weight status did not affect neonatal outcomes (Table 4).

Compared to normal weight women, obese and overweight mothers had lower weight gain (WG), with odds ratio (OR) of $0.2(0.1-0.4)$ and $0.4(0.2-0.7)$, respectively. This indicates that overweight and obesity were protective against excess maternal weight gain. Nevertheless, obese women showed higher risk of developing

Table 1 Characteristics of the participating pregnant women

\begin{tabular}{|c|c|c|c|c|}
\hline & $\begin{array}{l}\text { Normal weight } \\
N=65\end{array}$ & $\begin{array}{l}\text { Overweight } \\
N=66\end{array}$ & $\begin{array}{l}\text { Obese } \\
N=127\end{array}$ & $p$-value* \\
\hline & N (\%) & N (\%) & N (\%) & \\
\hline Age (years)* & & & & $<0.001$ \\
\hline$\leq 19$ & $12(18.5)$ & $2(3.0)^{a}$ & $1(0.8)^{a}$ & \\
\hline $20-35$ & $46(70.8)$ & $49(74.2)$ & $91(71.6)$ & \\
\hline$>35$ & $7(10.8)$ & $15(22.7)^{a}$ & $35(27.6)^{a}$ & \\
\hline Pregnancies (including cur & & & & 0.187 \\
\hline 1 & $18(27.7)$ & $11(16.7)$ & $19(15.0)$ & \\
\hline 2 & $19(29.2)$ & $18(27.3)$ & $33(26.0)$ & \\
\hline$\geq 3$ & $28(43.1)$ & $37(56.1)$ & 75 (59.6) & \\
\hline Previous C-section & & & & 0.366 \\
\hline Zero & $44(67.7)$ & $35(53.0)$ & $68(53.5)$ & \\
\hline 1 & $14(21.5)$ & $20(30.3)$ & $36(28.4)$ & \\
\hline$\geq 2$ & $7(10.8)$ & $11(16.7)$ & $23(18.1)$ & \\
\hline Smoking habits & $9(13.8)$ & $17(25.8)$ & $20(15.8)$ & 0.141 \\
\hline Cronic hypertension & $4(50.0)$ & $17(81.0)$ & $47(74.6)$ & 0.231 \\
\hline Prepregnancy diabetes & $4(6.2)$ & $9(13.6)^{a}$ & $20(15.7)^{a}$ & $<0.001$ \\
\hline Family history & & & & \\
\hline Diabetes & $54(83.1)$ & $48(72.7)$ & $93(73.2)$ & 0.266 \\
\hline Obesity & $17(26.2)$ & $24(36.4)$ & $56(44.1)^{a, b}$ & 0.051 \\
\hline Hypertension & $44(67.7)$ & $49(74.2)$ & $101(79.5)$ & 0.195 \\
\hline Cardiovascular disease & $14(21.5)$ & $19(28.8)$ & $43(33.9)$ & 0.206 \\
\hline Hypercholesterolemia & $15(23.1)$ & $20(30.3)$ & $41(32.3)$ & 0.410 \\
\hline
\end{tabular}

* Chi-square test

a statistically different from the control group $(p<0.05)$

${ }^{b}$ statistically different from the overweight group $(p<0.05)$ 
Table 2 Maternal outcomes

\begin{tabular}{|c|c|c|c|c|}
\hline & $\begin{array}{l}\text { Normal weight } \\
N=65\end{array}$ & $\begin{array}{l}\text { Overweight } \\
N=66\end{array}$ & $\begin{array}{l}\text { Obese } \\
N=127\end{array}$ & ${ }^{*} p$-value \\
\hline & Mean \pm sd & Mean \pm sd & Mean \pm sd & \\
\hline Initial weight (Kg) & $57.1 \pm 5.7$ & $69.9 \pm 6.7^{a}$ & $91.2 \pm 13.7^{\mathrm{a}, \mathrm{b}}$ & $<0.001$ \\
\hline Final weight (Kg) & $71.5 \pm 7.1$ & $82.9 \pm 7.6^{a}$ & $100.7 \pm 15.4^{\mathrm{a}, \mathrm{b}}$ & $<0.001$ \\
\hline Weight gain (Kg) & $14.4 \pm 4.6$ & $12.8 \pm 5.7$ & $9.6 \pm 7.5^{\mathrm{a}, \mathrm{b}}$ & $<0.001$ \\
\hline Prepregnancy BMI $\left(\mathrm{Kg} / \mathrm{m}^{2}\right)$ & $22.4 \pm 1.7$ & $27.5 \pm 1.3^{\mathrm{a}}$ & $36.2 \pm 4.9^{\mathrm{a}, \mathrm{b}}$ & $<0.001$ \\
\hline \multirow[t]{2}{*}{ Gestational BMI (Kg/m²) } & $28.1 \pm 2.4$ & $32.6 \pm 2.7^{a}$ & $39.9 \pm 5.5^{\mathrm{a}, \mathrm{b}}$ & $<0.001$ \\
\hline & N (\%) & N (\%) & N (\%) & tp-value \\
\hline Weight gain (Kg) & & & & $<0.001$ \\
\hline$<8$ & $5(7.8)$ & $12(18.2)$ & $58(45.7)^{a, b}$ & \\
\hline $8-16$ & $36(55.4)$ & $36(54.6)$ & $42(33.1)^{\mathrm{a}, \mathrm{b}}$ & \\
\hline$>16$ & $24(36.9)$ & $18(27.3)$ & $27(21.3)$ & \\
\hline Gestational BMI (Kg/m²) & & & & $<0.001$ \\
\hline Underweight & $7(10.8)$ & $0(0.0)^{a}$ & $0(0.0)^{\mathrm{a}}$ & \\
\hline Adequate & $33(50.8)$ & $5(7.6)^{a}$ & $0(0.0)^{\mathrm{a}, \mathrm{b}}$ & \\
\hline Overweight & $23(35.4)$ & $35(53.0)^{a}$ & $8(6.3)^{a, b}$ & \\
\hline Obese & $2(3.1)$ & $26(39.4)^{a}$ & $119(93.7)^{a, b}$ & \\
\hline Physical activity (yes) & $17(26.2)$ & $34(51.5)^{a}$ & $55(43.3)^{a}$ & 0.010 \\
\hline Intercurrent diseases & $30(46.2)$ & $26(39.4)$ & $62(48.8)$ & 0.458 \\
\hline Urinary infection & $8(12.5)$ & $8(11.9)$ & $30(23.6)$ & \\
\hline Genital infection & $12(18.8)$ & $12(17.9)$ & $15(11.8)$ & \\
\hline GH or PE & $4(50.0)$ & $4(19.0)$ & $16(25.4)$ & \\
\hline GDM & $8(12.3)$ & $22(33.3)^{a}$ & $50(39.4)^{a}$ & $<0.001$ \\
\hline MGH & $12(18.4)$ & $15(22.7)^{\mathrm{a}}$ & $27(21.2)^{a}$ & 0.005 \\
\hline HbA1c (\%) [3rd trimester] & & & & 0.075 \\
\hline$<6.5$ & $61(93.8)$ & $53(80.3)$ & $102(80.3)$ & \\
\hline $6.5-8.0$ & $3(4.6)$ & $13(19.7)$ & $23(18.1)$ & \\
\hline$\geq 8.0$ & $1(1.6)$ & $0(0.00)$ & $2(1.57)$ & \\
\hline
\end{tabular}

* ANOVA; Tukey test

+ Chi-square test

a statistically different from the control group $(p<0.05)$

${ }^{b}$ statistically different from the overweight group $(p<0.05)$

hypertension $(\mathrm{OR}=7.0 ; 3.1-15.9)$, hyperglycemic disturbances $(\mathrm{OR}=5.5 ; 2.9-10.6)$ and HbA1c > $6.5 \%(\mathrm{OR}=3.7$; 1.2-11.1) during pregnancy. Maternal weight status did not affect neonatal outcomes (Table 5).

\section{Discussion}

In the present study, overweight and obesity were associated with increased maternal weight, and gestational BMI, as well as higher prevalence of GDM and MGH. In the obese group, the proportion of LGA babies with disproportionate ponderal index $(\geq 2.98)$, placenta weight and placental index (PI) were higher, and hospitalstay length was longer. Obesity was associated with higher risk of developing hypertension, hyperglycemia and HbA1c $\geq 6.5 \%$ in late pregnancy. Unexpectedly, obesity and overweight were protective factors against maternal weight gain, without affecting neonatal outcomes.

Obese and overweight women were heavier and showed higher prepregnancy BMI, which was proportional to their nutritional status. These features persisted throughout pregnancy and were associated with hypertension, GDM and MGH. Similar results have also been observed in previous studies showing association of increased BMI with development of hypertension and hyperglycemia [3, 7, 22-24].

In this study, logistic regression analysis indicated obesity as a risk factor for gestational hypertension and hyperglycemia, increasing the likelihood of their occurrence seven and five-fold, respectively. This maternal characteristic was also a determining factor for the fourfold increase in the occurrence of $\mathrm{HbA} 1 \mathrm{c} \geq 6.5 \%$ at the 
Table 3 Delivery and neonatal outcomes

\begin{tabular}{|c|c|c|c|c|}
\hline & Normal weight & Overweight & Obese & ${ }^{*} p$-value \\
\hline & $N=65$ & $N=66$ & $N=127$ & \\
\hline & N (\%) & N (\%) & N (\%) & \\
\hline Mode of delivery & & & & 0.304 \\
\hline Vaginal & $25(39.5)$ & $21(31.8)$ & $35(27.6)$ & \\
\hline Cesarean & $40(61.5)$ & $45(68.2)$ & $92(72.4)$ & \\
\hline Gestational age (weeks) & & & & 0.494 \\
\hline$<37$ & $3(4.6)$ & $5(7.6)$ & $12(9.4)$ & \\
\hline$\geq 37$ & $62(95.4)$ & $61(92.4)$ & $115(90.6)$ & \\
\hline New Ballard (weeks) \pm & & & & 0.115 \\
\hline$<37$ & $3(5.8)$ & $6(10.9)$ & $19(17.1)$ & \\
\hline$\geq 37$ & $49(94.2)$ & $49(89.1)$ & $92(82.9)$ & \\
\hline Birth weight (g) & & & & 0.304 \\
\hline$<2500$ & $4(6.2)$ & $2(3,0)$ & $2(1.6)$ & \\
\hline $2500-4000$ & $57(87.7)$ & $61(92.4)$ & $113(89.0)$ & \\
\hline$\geq 4000$ & $4(6.2)$ & $3(4.6)$ & $12(9.4)$ & \\
\hline Weight class & & & & 0.021 \\
\hline SGA & $8(12.3)$ & $10(15,2)$ & $6(4.7)^{a, b}$ & \\
\hline AGA & $54(83.1)$ & $53(80.3)$ & $104(81.9)$ & \\
\hline LGA & $3(4.6)$ & $3(4.6)$ & $17(13.4)$ & \\
\hline Ponderal index (PI) & & & & 0.037 \\
\hline$<2.98$ (proportional) & $50(76.9)$ & $46(69,7)$ & $75(59.1)$ & \\
\hline \multirow[t]{2}{*}{$\geq 2.98$ (disproportionate) } & $15(23.1)$ & $20(30.3)$ & $52(40.9)^{a, b}$ & \\
\hline & Mean $\pm s d$ & Mean $\pm s d$ & Mean $\pm s d$ & $\# p$-value \\
\hline Weight (g) & $3210.2 \pm 469.2$ & $3208.9 \pm 430.4$ & $3365.9 \pm 483.4$ & 0.199 \\
\hline Length (cm) & $48.6 \pm 2.2$ & $48.4 \pm 2,0$ & $48.6 \pm 2.1$ & 0.759 \\
\hline Head Circumf (cm) & $34.4 \pm 1.5$ & $34.4 \pm 1,3$ & $34.8 \pm 1.5$ & 0.094 \\
\hline Thoracic Circumf (cm) & $32.9 \pm 1.9$ & $32.8 \pm 1,7$ & $33.6 \pm 2.0^{\mathrm{a}, \mathrm{b}}$ & 0.006 \\
\hline Abdom Circumf (cm) & $31.1 \pm 2.3$ & $30.7 \pm 1,8$ & $31.6 \pm 2.3^{\mathrm{a}, \mathrm{b}}$ & 0.032 \\
\hline 1-min Apgar & $8.3 \pm 1.4$ & $8.2 \pm 1,8$ & $7.8 \pm 1.5$ & 0.076 \\
\hline 5-min Apgar & $9.3 \pm 0.8$ & $9.3 \pm 0.9$ & $9.1 \pm 0.8$ & 0.143 \\
\hline 10-min Apgar & $9.7 \pm 0.5$ & $9.6 \pm 0.6$ & $9.5 \pm 0.6$ & 0.071 \\
\hline Ponderal index & $2.8 \pm 0.3$ & $2.8 \pm 0.3$ & $2.9 \pm 0.3^{\mathrm{a}, \mathrm{b}}$ & 0.005 \\
\hline Placental weight (g) & $560.1 \pm 138,9$ & $574,6 \pm 119,8$ & $635,6 \pm 156,6^{a, b}$ & 0.001 \\
\hline Placental index & $0.2 \pm 0.0$ & $0.2 \pm 0.0$ & $0.2 \pm 0.0^{a, b}$ & 0.037 \\
\hline
\end{tabular}

$\pm N=217$ [41 newborns with incomplete data]

* Chi-square test

\# ANOVA; Tukey test

a statistically different from the control group $p<0.05)$

b statistically different from the overweight group $(p<0.05)$

end of pregnancy. Hypertension and hyperglycemia associated with central obesity (in women, BMI $\geq 30 \mathrm{Kg} / \mathrm{m}^{2}$ or waist circumference $\geq 80 \mathrm{~cm}$ ) are clinical criteria for the diagnosis of metabolic syndrome (MS), whose physiopathological basis is the association between obesity and insulin resistance [25].
Insulin resistance, classically considered as a characteristic of healthy pregnancy, is more pronounced in pregnancies complicated by diabetes [26]. The relationship between maternal MS and hyperglycemia during pregnancy was first reported by Bo et al. [27] and has been recently corroborated by our research group [28, 29]. 
Table 4 Neonatal outcomes ${ }^{ \pm}$

\begin{tabular}{|c|c|c|c|c|}
\hline & $\begin{array}{l}\text { Normal weight } \\
N=65\end{array}$ & $\begin{array}{l}\text { Overweight } \\
N=66\end{array}$ & $\begin{array}{l}\text { Obese } \\
N=127\end{array}$ & ${ }^{*} p$-value \\
\hline & N (\%) & N (\%) & N (\%) & \\
\hline Hypoglycemia & 0 & 0 & $1(1.0)$ & 0.620 \\
\hline Malformation & $2(4.4)$ & $2(4.0)$ & $6 q$ & 0.833 \\
\hline \multirow[t]{2}{*}{ Phototherapy } & $14(23.0)$ & $10(16.4)$ & $37(37.0)$ & 0.091 \\
\hline & Mean \pm SD & Mean $\pm S D$ & Mean \pm SD & $\# p$-value \\
\hline Hematocrit (\%) & $48.3 \pm 5.3$ & $51.0 \pm 9.3$ & $49.6 \pm 5.4$ & 0.163 \\
\hline Hemoglobin (g/dL) & $16.2 \pm 1.8$ & $16.4 \pm 1.9$ & $16.3 \pm 2.4$ & 0.832 \\
\hline Ind. Bilirubin (mg/dL) & $1.9 \pm 0.5$ & $2.0 \pm 0.7$ & $2.0 \pm 0.6$ & 0.575 \\
\hline White cells $\left(\times 10^{3} / \mathrm{mm}^{3}\right)$ & $14755 \pm 3095.8$ & $14786 \pm 6627.7$ & $14543 \pm 4332.8$ & 0.975 \\
\hline Red cells $\left(/ \mathrm{mm}^{3}\right)$ & $4.8 \pm 0.6$ & $4.4 \pm 0.5$ & $4.6 \pm 0.5$ & 0.082 \\
\hline Glucose levels (mg/dL) & $63.4 \pm 16.3$ & $65.8 \pm 25.5$ & $66.0 \pm 20.5$ & 0.091 \\
\hline Hospitalization (days) & $3.0 \pm 1.5$ & $3.0 \pm 1.4$ & $3.9 \pm 3.9^{\mathrm{a}, \mathrm{b}}$ & 0.005 \\
\hline
\end{tabular}

$\pm N=204$ [54 infants with incomplete records]

* Chi-square test

\# ANOVA; Tukey test

${ }^{a}$ statistically different from the control group $(p<0.05)$

${ }^{b}$ statistically different from the overweight group $(p<0.05)$

Thus, in addition to the 13-15\% rates of pregestational DM observed in the present study, the overweight and obese groups were expected to show elevated rates of $\mathrm{MGH}$ or GDM, and a high proportion of $\mathrm{HbA1c} \geq 6.5 \%$. However, although elevated rates of MGH (about $22 \%$ ) and GDM (approximately 30 to $40 \%$ ) were indeed observed, only $20.0 \%$ of the overweight and obese participants showed $\mathrm{HbA1c} \geq 6.5 \%$.

All overweight and obese women participating in this study received individualized dietary advice and were encouraged to engage in physical activity regardless of diagnosis of diabetes or hyperglycemia. Indeed, 51.5 and $43.3 \%$ of overweight and obese pregnant women, respectively, adhered to physical activity recommendations, but

Table 5 Odds ratio (OR) and confidence interval (Cl $95 \%)$ of prepregnancy BMI vs maternal and neonatal outcomes

\begin{tabular}{|c|c|c|c|c|}
\hline & \multicolumn{2}{|c|}{$\begin{array}{l}\text { Obese vs normal } \\
\text { weight }\end{array}$} & \multicolumn{2}{|c|}{$\begin{array}{l}\text { Overweight vs norma } \\
\text { weight }\end{array}$} \\
\hline & $\mathrm{OR}$ & Cl $95 \%$ & $\mathrm{OR}$ & Cl $95 \%$ \\
\hline \multicolumn{5}{|l|}{ Mother } \\
\hline Weight gain $\geq 16 \mathrm{Kg}$ & 0.2 & $0.1-0.4$ & 0.4 & $0.2-0.7$ \\
\hline Hypertension & 7.0 & $3.1-15.9$ & 2.1 & $1.1-3.9$ \\
\hline Hyperglycemia & 5.5 & $2.9-10.6$ & 1.3 & $0.7-2.6$ \\
\hline $\mathrm{HbA} 1 \mathrm{c} \geq 6.5 \%$ & 3.7 & $1.2-11.1$ & 1.0 & $0.5-2.2$ \\
\hline \multicolumn{5}{|l|}{ Newborn } \\
\hline Weight & 2.3 & $0.8-6.6$ & 1.9 & $0.7-5.4$ \\
\hline Weight classes & 1.0 & $0.4-2.1$ & 0.8 & $0.4-1.7$ \\
\hline 1-min Apgar score & 0.4 & $0.1-1.1$ & 0.6 & $0.2-1.5$ \\
\hline 5-min Apgar score & 2.0 & $0.1-32.0$ & 1.9 & $0.1-31.5$ \\
\hline
\end{tabular}

these measures did not prevent the occurrence of MGH or GDM, probably because the period between admission and diagnostic testing for MGH/GDM was short (about four weeks). Nonetheless, there was a $60-70 \%$ reduction in the risk of excessive weight gain, which may have contributed to the lower weight gain observed in the obese group, as well as to the significant rates of overweight and obese women (35 to $40 \%$ ) moving to lower BMI classes in late pregnancy, and the achievement of maternal hyperglycemia control (HbA1c levels $<6.5 \%$ ) in $80 \%$ of overweight and obese women.

The relationship of diet/exercise with maternal weight remains controversial. Several studies have evaluated the effects of dietary advice alone or associated with exercise, on maternal weight gain, but no consistent results have been obtained [30-33]. A recent meta-analysis has suggested that compared to unsupervised physical activity and diet interventions, supervised exercise plus diet programs were most effective in managing weight among overweight or obese pregnant and postpartum women [34].

In this study, LGA infants, with $\mathrm{PI} \geq 2.98$ and higher thoracic and abdominal circumference measures, as well as increased placental weight and placental índex were more frequent in the obese group. According to previous studies, gestational BMI and DM or hyperglycemia are independent risk factors for excessive fetal growth $[7,12,35,36]$. Moreover, macrosomia, disproportionate growth, placentomegaly, high placental index, and increased fetal measures (especially abdominal circumference) have been considered common features in babies born to diabetic mothers $[19,20,35]$. In Brazil, a recent 
review has shown that a large proportion of women are overweight or obese at the beginning of pregnancy, and that this is associated with higher risk of excessive weight gain, cesarean delivery, and fetal macrosomia [37].

In our study, overweight and obesity were identified as preventive factors against excessive weight gain without risk for the baby. Thus, the adverse neonatal outcomes here observed were probably caused by maternal hyperglycemia. Previous results obtained by our research group show that fetal macrosomia is significantly associated with prepregnancy BMI, hyperglycemic levels, and personal history of macrosomia in pregnancies complicated by diabetes or mild hyperglycemia [38]. A cohort study of 6,125 deliveries, using logistic multivariate analysis to exclude potential confounding variables, has demonstrated that only neonatal macrosomia and meconium aspiration syndrome remain significantly associated with maternal overweight and obesity [39]. Macrosomia and excessive fetal growth are frequently associated with $\mathrm{BMI} \geq 25 \mathrm{~kg} / \mathrm{m}^{2}$ and maternal diabetes or hyperglycemia, which are also interdependent. Therefore, it is practically impossible to determine the intensity of such effects.

Although indirectly, our results corroborate the usefulness of dietary advice plus exercise as a preventive intervention against excessive weight gain in pregnancies complicated by overweight or obesity. However, this study has some limitations that include the adoption of a cross-sectional rather than a randomized controlled design, the potential bias of confounding factors relative to missing personal information (pre-gestational weight, compliance to treatment protocol); and sample size, which might not have been large enough for the evaluation of neonatal outcomes and a more elaborate statistical analysis (adjustment for age, parity and maternal weight or multiple regression analysis).

\section{Conclusions}

In the present study, adverse pregnancy outcomes were associated with obesity and overweight, and indirectly related to maternal hyperglycemia. Obesity was a determinant risk factor for hypertension, hyperglycemia, and increased HbA1c levels at the end of pregnancy. Overweight elevated the risk of hypertension, and both obesity and overweight were protective factors against excessive maternal weight gain without affecting neonatal outcomes. These findings indicate that adverse outcomes resulted from inadequate nutritional status during pregnancy, and indirectly underscore the importance of identifying and treating inadequate weight status during pregnancy.

\section{Acknowledgements}

The authors are thankful to the São Paulo Research Foundation (Fundação de Amparo à Pesquisa do Estado de São Paulo_FAPESP, grant \# 2012 51257-9/PP-SUS 2012), and the Research Support Group (Escritório de Apoio à Pesquisa of Botucatu Medical School/UNESP) for their technical support in statistical analysis.

\section{Authors' contributions}

IMPC substantially contributed to study conception and design, as well as data analysis and interpretation. JMV was responsible for data collection. JBM, CGM and RAAC supervised data collection, and contributed to data analysis and interpretation.All authors have read and approved the final manuscript.

\section{Competing interests}

The authors declare that they have no competing interests.

Received: 27 May 2015 Accepted: 29 July 2016

Published online: 27 August 2016

\section{References}

1. World Health Organization. Obesity: preventing and managing the global epidemic. Report of a WHO consultation. Geneva: World Health Organization technical report series; 2000.

2. World Health Organization. Global strategy on diet, physical activity and health: obesity and overweight. Geneva: World Health Organization; 2003.

3. World Health Organization (WHO). Obesity and overweight. Fact sheet No. 311. 2006. [www.who.int/mediacentre/factsheets/fs311/en/index.html]. Last accessed 21 April 2016.

4. Mattar R, Torloni MR, Betrán AP, Merialdi M. Obesity and pregnancy. Rev Bras Ginecol Obstet. 2009;31:107-10.

5. World Health Organization. WHO Expert Committee on Physical status: the Use and Interpretation of Anthropometry. WHO Technical report series: 854. Geneva: World Health Organization; 1995.

6. Ministério da Saúde (BR). Secretaria de Atenção à Saúde. Departamento de Ações Programáticas Estratégicas. Área Técnica de Saúde da Mulher. Prénatal e puerpério: atenção qualificada e humanizada: manual técnico. 3a ed. Braślia DF: Ministério da Saúde; 2006

7. Nomura RMY, Paiva LV, Costa VN, Liao AW, Zugaib M. Influência do estado nutricional materno, ganho de peso e consumo energético sobre o crescimento fetal, em gestações de alto risco. Rev Bras Ginecol Obstet. 2012;34:107-12.

8. Institute of Medicine (IOM). Subcommitee on nutritional status and weight gain during pregnancy. Institute of Medicine. Nutrition during pregnancy. Washington, DC: Nat Acad Press; 2009.

9. Atalah SE, Castilho LC, Castro SR, Aldea PA. Propuesta de um nuevo estándar de evalución nutricional en embarazadas. Rev Med Chil. 1997:125:1429-36

10. Assunção PL, Melo ASO, Gondim SSR, Benício MHA, Amorim MMR, Cardoso MAA, et al. Ganho ponderal e desfechos gestacionais em mulheres atendidas pelo Programa de Saúde da Família em Campina Grande, PB (Brasil). Rev Bras Epidemiol. 2007;10:352-60.

11. Torloni MR, Betrán AP, Horta BL, Nakamura MU, Atallah AN, Moron AF, et al. Prepregnancy BMI and the risk of gestational diabetes: a systematic review of the literature with meta-analysis. Obes Rev. 2009;10(2):194-203.

12. Yu Z, Han S, Zhu J, Sun X, Ji C, Guo X. Pre-Pregnancy Body Mass Index in Relation to Infant Birth Weight and Offspring Overweight/Obesity: A Systematic Review and Meta-Analysis. PLoS ONE 8(4): e61627. doi:10.1371/journal.pone.0061627.

13. Guelinckx I, Devlieger R, Beckers K, Vansant G. Maternal obesity: pregnancy complications, gestational weight gain and nutrition. Obes Rev. 2007;9:14-50.

14. Sebastian Manzanares G, Angel Santalla H, Irene Vico Z, Lopez Criado MS, Alicia Pineda $L$, et al. Abnormal maternal body mass index and obstetric and neonatal outcome. J Matern Fetal Neonatal Med. 2012;25:308-12.

15. Simmons D. Diabetes and obesity in pregnancy. Best Practice \& Research Clinical Obstetrics \& Gynaecol. 2011;25:25-36.

16. Adamo KB, Ferraro ZM, Brett KE. Pregnancy is a critical period for prevention of obesity and cardiometabolic Risk. Can J Diabetes. 2012;36:133-41.

17. World Health Organization. Diet, nutrition and the prevention of chronic diseases. Tech Rep Ser. 2003;916:1-149.

18. American Diabetes Association. Gestational Diabetes Mellitus: position statements. Diabetes Care. 2012;5:S51-S71.

19. Rudge MVC, Calderon IMP, Ramos MD, Brasil MAM, Rugolo LMSS, Bossolan G, Od Land JO. Hiperglicemia materna diária diagnosticada pelo perfil glicêmico: 
um problema de saúde pública materno e perinatal. Rev Bras Ginecol Obstet. 2005;27:691-7.

20. Rudge MV, Calderon IM, Ramos MD, Abbade JF, Rugolo LM. Perinatal outcome of pregnancies complicated by diabetes and by maternal daily hyperglycemia not related to diabetes. A retrospective 10-year analysis. Gynecol Obstet Invest. 2000;50:108-12.

21. American College of Obstetricians and Gy- necologists. ACOG Committee opinion. Number 267, January 2002: Exercise during pregnancy and the postpartum period. Ob- stet Gynecol. 2002;99:171-3.

22. Abenhaim HA, Kinch RA, Morin J, Benjamin A, Usher R. Effect of prepregnancy body mass index categories on obstetrical and neonatal utcomes. Arch Gynecol Obstet. 2007;275:39-43.

23. Fortner RT, Pekow P, Solomon CG, Markenson G, Chasan-Taber L. Prepregnancy body mass index, gestational weight gain, and risk of hypertensive pregnancy among Latina women. Am J Obstet Gynecol. 2009:200:e1-7.

24. Herring SJ, Oken E, Rifas-Shiman SL, Rich-Edwards JW, Stuebe AM, Kleinman KP, Gillman NW. Weight gain in pregnancy and risk of maternal hyperglycemia. Am J Obstet Gynecol. 2009;201:e1-7.

25. International Diabetes Association (IDF). The IDF consensus worldwide definition of the metabolic syndrome. Brussels: IDF; 2007.

26. Hollingsworth DR. Maternal metabolism in normal pregnancy and pregnancy complicated by diabetes mellitus. Clin Obstet Gynecol. 1985;28:457-72

27. Bo S, Menato G, Gallo ML, Bardelli C, Lezo A, Signorile A, Gambino R, Cassader M, Massobrio M, Pagano G. Mild gestational hyperglycemia, the metabolic syndrome and adverse neonatal outcomes. Acta Obstet Gynecol Scand. 2004:83:335-40

28. Negrato CA, Javanovic L, Tambascia MA, Calderon IMP, Geloneze B, DIAS A, Rudge MVC. Mild Gestacional hyperglycemia as a risk factor for metabolic syndrome in pregnancy and adverse perinatal outcomes. Diabetes Metab Res Rev. 2008;24:324-330.

29. Negrato CA, Javanovic L, Tambascia MA, Calderon IMP, Geloneze B, Dias A, Rudge MVC. Association between insulin resistance, glucose intolerance, and hypertension in pregnancy. Metab Syndr Relat Disord. 2009;7:53-9.

30. Wolff S, Legarth J, Vangsgaard K, Toubro S, Astrup A. A randomized trial of the effects of dietary counseling on gestational weight gain and glucose metabolism in obese pregnant women. Int J Obes. 2008;32:495-501.

31. Thornton YS, Smarkola C, Kopacz SM, Ishoof SB. Perinatal outcomes in nutritionally monitored obese pregnant women: a randomized clinical trial. J Natl Med Assoc. 2009;01:569-77.

32. Guelinckx I, Devlieger R, Mullie P, Vansant G. Effect of lifestyle intervention on dietary habits, physical activity, and gestational weight gain in obese pregnant women: a randomized controlled trial. Am J Clin Nutr. 2010;91:373-80.

33. Nascimento S, Surita F, Parpinelli M, Siani S, Pinto e Silva J. The effect of an antenatal physical exercise programme on maternal/perinatal outcomes and quality of life in overweight and obese pregnant women: a randomised clinical trial. BJOG. 2011:118:1455-63.

34. Choi J, Fukuoka Y, Lee JH. The Effects of Physical Activity and Physical Activity plus Diet Interventions on Body Weight in Overweight or Obese Women who are Pregnant or in Postpartum: A Systematic Review and Meta Analysis of Randomized Controlled Trials. Prev Med. 2013;56(6):351-64.

35. Najafian M, Cheraghi M. Occurrence of Fetal Macrosomia Rate and Its Maternal and Neonatal Complications: A 5-Year Cohort Study. ISRN Obstetrics and Gynecology. 2012; Article ID 353791 (5 pages), doi:10.5402/ 2012/353791.

36. HAPO Study Cooperative Research Group. Hyperglycaemia and adverse pregnancy outcome (HAPO) study: associations with maternal body mass index. Int J Obstet Gynecol. 2010;117:575-84

37. Godoy AC, Nascimento SL, Surita FG. A systematic review and meta-analysis of gestational weight gain recommendations and related outcomes in Brazil. Clinics. 2015;70(11):758-64.

38. Kerche LT, Abbade JF, Costa RA, Rudge MV, Calderon IM. Fetal macrosomia risk factors in pregnancies complicated by diabetes or daily hyperglycemia. Rev Bras Ginecol Obstet. 2005;27(10):580-7.

39. Narchi $\mathrm{H}$, Skinner A. Overweight and obesity in pregnancy do not adversely affect neonatal outcomes: new evidence. J Obstet Gynaecol. 2010;30(7):679-86.

\section{Submit your next manuscript to BioMed Central and we will help you at every step:}

- We accept pre-submission inquiries

- Our selector tool helps you to find the most relevant journal

- We provide round the clock customer support

- Convenient online submission

- Thorough peer review

- Inclusion in PubMed and all major indexing services

- Maximum visibility for your research

Submit your manuscript at www.biomedcentral.com/submit

) Biomed Central 